\title{
Directed evolution of a three-finger neurotoxin by using cDNA display yields antagonists as well as agonists of interleukin-6 receptor signaling
}

\author{
Mohammed Naimuddin ${ }^{1,2,5^{*}}$, Suzuko Kobayashi ${ }^{3}$, Chihiro Tsutsui ${ }^{4}$, Masayuki Machida ${ }^{1}$, Naoto Nemoto ${ }^{2,5}$,
} Takafumi Sakai ${ }^{4}$, Tai Kubo $3,6,7^{*}$

\begin{abstract}
Background: Directed evolution of biomolecules such as DNA, RNA and proteins containing high diversity has emerged as an effective method to obtain molecules for various purposes. In the recent past, proteins from nonimmunoglobulins have attracted attention as they mimic antibodies with respect to binding potential and provide further potential advantages. In this regard, we have attempted to explore a three-finger neurotoxin protein (3F). 3F proteins are small $(\sim 7 \mathrm{kDa})$, structurally well defined, thermally stable and resistant to proteolysis that presents them as promising candidates for directed evolution.

Results: We have engineered a snake $\alpha$-neurotoxin that belongs to the $3 \mathrm{~F}$ family by randomizing the residues in the loops involved in binding with acetylcholine receptors and employing CDNA display to obtain modulators of interleukin-6 receptor (IL-6R). Selected candidates were highly specific for IL-6R with dissociation constants and IC50s in the nanomolar range. Antagonists as well as agonists were identified in an IL-6 dependent cell proliferation assay. Size minimization yielded peptides of about one-third the molecular mass of the original proteins, without significant loss of activities and, additionally, lead to the identification of the loops responsible for function.

Conclusions: This study shows $3 \mathrm{~F}$ protein is amenable to introduce amino acid changes in the loops that enable preparation of a high diversity library that can be utilized to obtain ligands against macromolecules. We believe this is the first report of protein engineering to convert a neurotoxin to receptor ligands other than the parent receptor, the identification of an agonist from non-immunoglobulin proteins, the construction of peptide mimic of $\mathrm{IL}-6$, and the successful size reduction of a single-chain protein.
\end{abstract}

\section{Background}

In vitro evolution of proteins is an increasingly promising approach for introducing desired, novel changes that can modulate the properties and/or functions of proteins [1]. In this regard, technologies such as phage display, ribosome display, mRNA/cDNA display and others [2-6] that couple the phenotype (expressed proteins) to their genotype (DNA, mRNA or cDNA) have shown

\footnotetext{
*Correspondence: mnaimuddin@gmail.com; tai.kubo@aist.go.jp

'Applied Gene Technology, Institute for Biological Resources and Functions, National Institute of Advanced Industrial Science and Technology, Central 6, 1-1-1, Higashi, Tsukuba, Ibaraki 305-8566, Japan

${ }^{3}$ Molecular Neurophysiology, Neuroscience Research Institute, National Institute of Advanced Industrial Science and Technology, Central 6, 1-1-1 Higashi, Tsukuba, Ibaraki 305-8566, Japan

Full list of author information is available at the end of the article
}

considerable promise, allowing proteins with desired functions to be selected from large totally random and scaffold libraries [7].

Protein scaffolds can be either naturally occurring or de novo synthesized, and have defined structures that contain amenable regions such as loops that can be engineered to accommodate completely novel properties, in particular binding and inhibition [8,9]. Disulfide-containing scaffolds, such as $\alpha$-amylase inhibitor (tendamistat), bovine pancreatic trypsin inhibitor (BPTI; Kunitz domain), EETI-II (knottin) and related proteins are attractive due to their small size, defined structures and remarkable stability. These scaffolds have been successfully engineered for various purposes, such as protease inhibitors, although none have been reported to 
bind or inhibit macromolecules such as receptors [8]. Here, we report the engineering of a three-finger scaffold that provides a benchmark in the development of regulatory proteins that can modulate the function of interleukin 6 receptor (IL-6R).

3F proteins are found in a variety of organisms such as the elapidae snake and mammals, including humans [10-13]. These are small proteins (MW: 7-8 $\mathrm{kDa}$ ) with 4-5 disulfide bonds, $\beta$-structure(s) and three protruding loops that provide the topological basis for the threefinger structure $[10,14]$. The striking features of the 3F-protein family are strict conservation of cysteine frameworks and high sequence diversity in the loop (corresponding to finger) regions. This may reasonably make 3F toxins in nature with broad spectrum in target molecules, such as ion channels, receptors, proteases, etc [14]. This class of protein exhibits high temperature stability, resistance to proteases and low immunogenicity. The exceptional specificity of $3 \mathrm{~F}$ proteins for their respective receptors, conferred by the residues on the tips of the loops, has been extensively investigated $[15,16]$. These properties make $3 \mathrm{~F}$ proteins excellent candidates for evolutionary engineering aimed at obtaining molecules for research, diagnostics and therapeutics.

We chose IL-6R to obtain modulatory molecules from the $3 \mathrm{~F}$ snake neurotoxin library. Interleukin-6 (IL-6) is a multifunctional cytokine regulating cell growth, differentiation, and other cellular functions [17]. The activity of IL-6 is exerted through IL-6R [17-19], and IL-6 is known to play a role in the pathogenesis of a variety of diseases such as Rheumatoid arthritis, Castleman's disease and others $[18,20,21]$. Therefore, molecules regulating IL-6R-mediated signaling of IL-6 are important for research, diagnostics and therapeutics. In this paper, we report the identification of modulators of IL-6R from a 3F library, and demonstrate the potential of the 3F scaffold in generating novel molecules for macromolecular receptors. The approach involved the directed evolution of the 3F protein library using cDNA display [6]. Further, we identified the functional loops by minimizing the size of the scaffold while retaining function comparable to the intact scaffold. We believe this is the first report of the engineering of a three-finger scaffold for a macromolecular receptor, the simultaneous identification of agonist and antagonist molecules of IL-6R, the generation of a peptide mimic of IL-6, and the downstream engineering of the scaffold in order to identify the functional loops.

\section{Results}

\section{Overview of cDNA display technology}

An overview of the selection process using cDNA display technology is given in Figure 1A. The puromycin linker is central to this technology and facilitates rapid ligation of the mRNA, linking of the expressed protein to its genotype (mRNA), and rapid reverse transcription at relatively low temperature $\left(42^{\circ} \mathrm{C}\right)$ (Figure $\left.1 \mathrm{~B}\right)$. As a result, unlike related technologies [4,5], the expressed protein is linked to the cDNA (steps 3-5) which provides stability to the complex compared to the unstable mRNA [6]. Furthermore, the stability of cDNA facilitates selection under stringent conditions such as $\mathrm{pH}$, temperature, etc.

\section{Three-finger (3F) library construction and characterization}

The 3F scaffold used in this study is a novel snake $\alpha$-neurotoxin, MicTx3, isolated from the South American coral snake, Micrurus corallinus. The cysteine framework of this protein is conserved and is similar to that of other short $\alpha$-neurotoxins [10] (Figure 2A). Biochemical characterization of MicTx 3 provided its affinity $(29.5 \pm 7.9 \mathrm{nM})$ for acetylcholine binding protein (AChBP), and electrophysiological studies of its inhibition characteristics were determined by the blockage of nicotinic acetylcholine receptor (nAChR) $\alpha 7$ currents expressed in Xenopus oocytes (data not shown). The amino acid residues forming the loops and $\beta$-sheets were deduced by secondary structure prediction, together with information from the literature regarding conserved amino acid residues in different toxins involved in binding to the nAChR $[15,22]$. Computer modeling of MicTx3 by superimposition of its spatial structure ( $\beta$-sheets and loops) on those of other neurotoxins was found to be in good agreement (Figure 2B). The amino acids predicted to form the loops, including those putatively involved in binding to acetylcholine receptor, were subjected to randomization (Figure 2C). Residues T5-P10 in the Loop I (6 residues), K25-V34 in the loop II (10 residues) and A46-H52 in the loop III (7 residues) were randomized and a library constructed (Figure 2A and 2D). The amino acid residues predicted to form the $\beta$-sheets were left unaltered.

The full construct and sequences adopted for cDNA display of the 3F protein library are detailed in Additional file 1, Fig. S1 and Additional file 2, Table S1 online. After transcription, cell-free translation, cDNA display, purification and quantification, an estimated 1.2 $\times 10^{11}$ molecules was obtained and used for the affinity selection of IL-6R (Figure 1A).

The binding characteristics of the 3F initial library (R0) were determined by the affinity of the library for immobilized AChBP (a binder of the parental MicTx3) and IL-6R. It was found that the library binds negligibly to both IL-6R and AChBP (Figure 3A) suggesting that the library does not bind to the receptors via the constant regions (i.e., non-randomized $\beta$-sheet residues). These characteristics ensure that the library is suitable for generating novel 
(1)

A

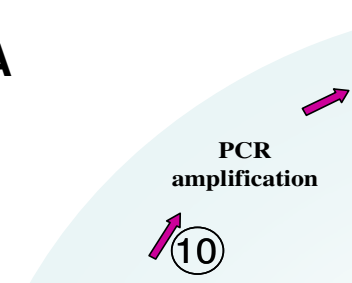

Random region

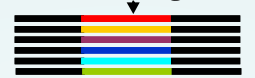

DNA library

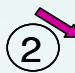
Transcription/ mRNA

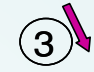

Recovery of

binding molecules

(9)

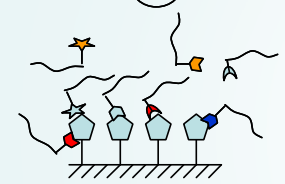

Selection cycle with

cDNA display

Selection of molecules

for desired targets

8

Purification via

C-terminal tag.
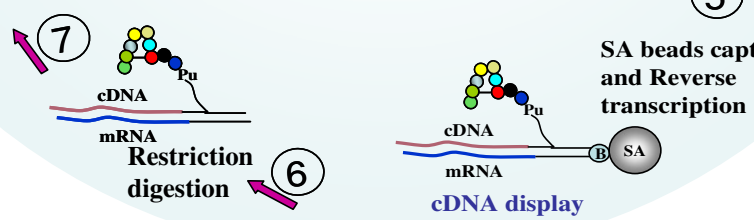

B

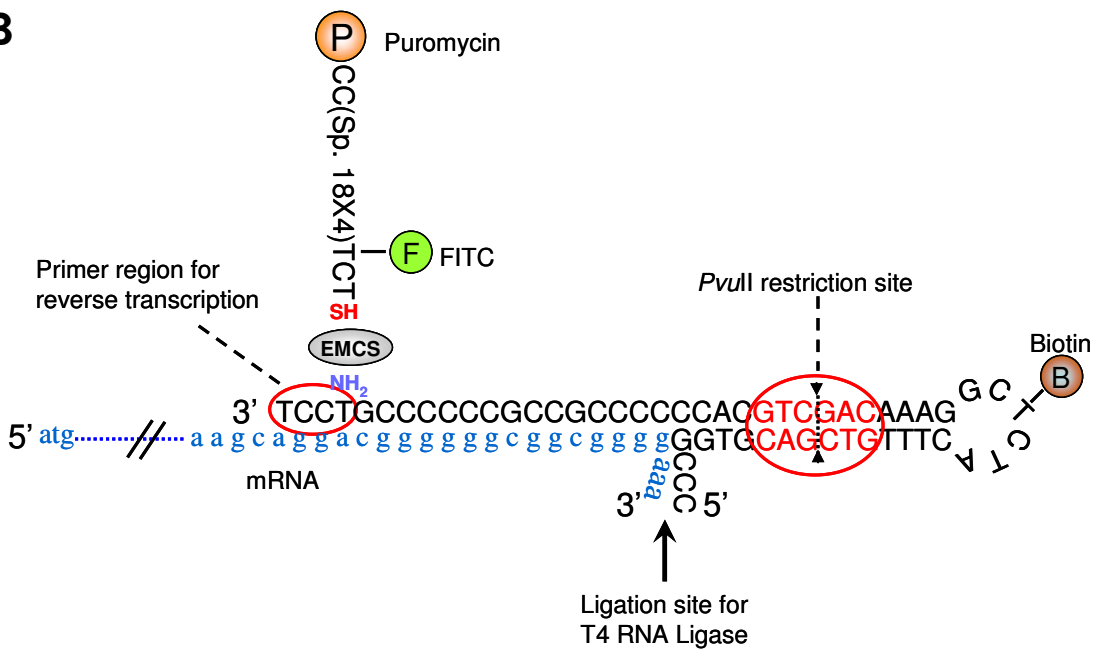

Figure 1 Overview of CDNA display and construction of the three-finger (3F) scaffold library. (A) CDNA display is based on the formation of a covalent fusion between the expressed protein (phenotype) and the encoding CDNA (genotype) via a puromycin attached to an oligonucleotide linker. The puromycin linker is central to this technology (see B). In step 1, the library is prepared with the construct to be adopted for the cDNA display (Additional file 1, Fig. S1 and Additional file 2, Table S1 online), transcribed into mRNA and ligated to the puromycin linker in the presence of T4 RNA ligase (steps 2 and 3). The mRNA-linker conjugate is then translated in a cell-free translation system (reticulocyte lysate) and the covalent linkage between the linker and protein is formed in the presence of high salt (step 4). Rapid purification is achieved using biotin-streptavidin. cDNA is then synthesized by reverse transcription in step 5 utilizing the 'built-in' primer of the linker. In step 6, the genotype-phenotype complex is released from the beads by restriction digestion with Pvull. Further, full length proteins are purified via the C-terminal 6xHis (step 7). Following selection of molecules against the immobilized targets, the bound molecules are recovered, purified, amplified (steps 8-10) and used in the next round of selection. (B) Schematic of the Puromycin linker and its functional features. The puromycin linker used in this study consists of four essential functional features. First, a ligation site for mRNA, a biotin moiety for rapid purification using immobilized streptavidin (SA), a primer region for reverse transcription and a restriction site for the release of the complex from the immobilized SA beads. 


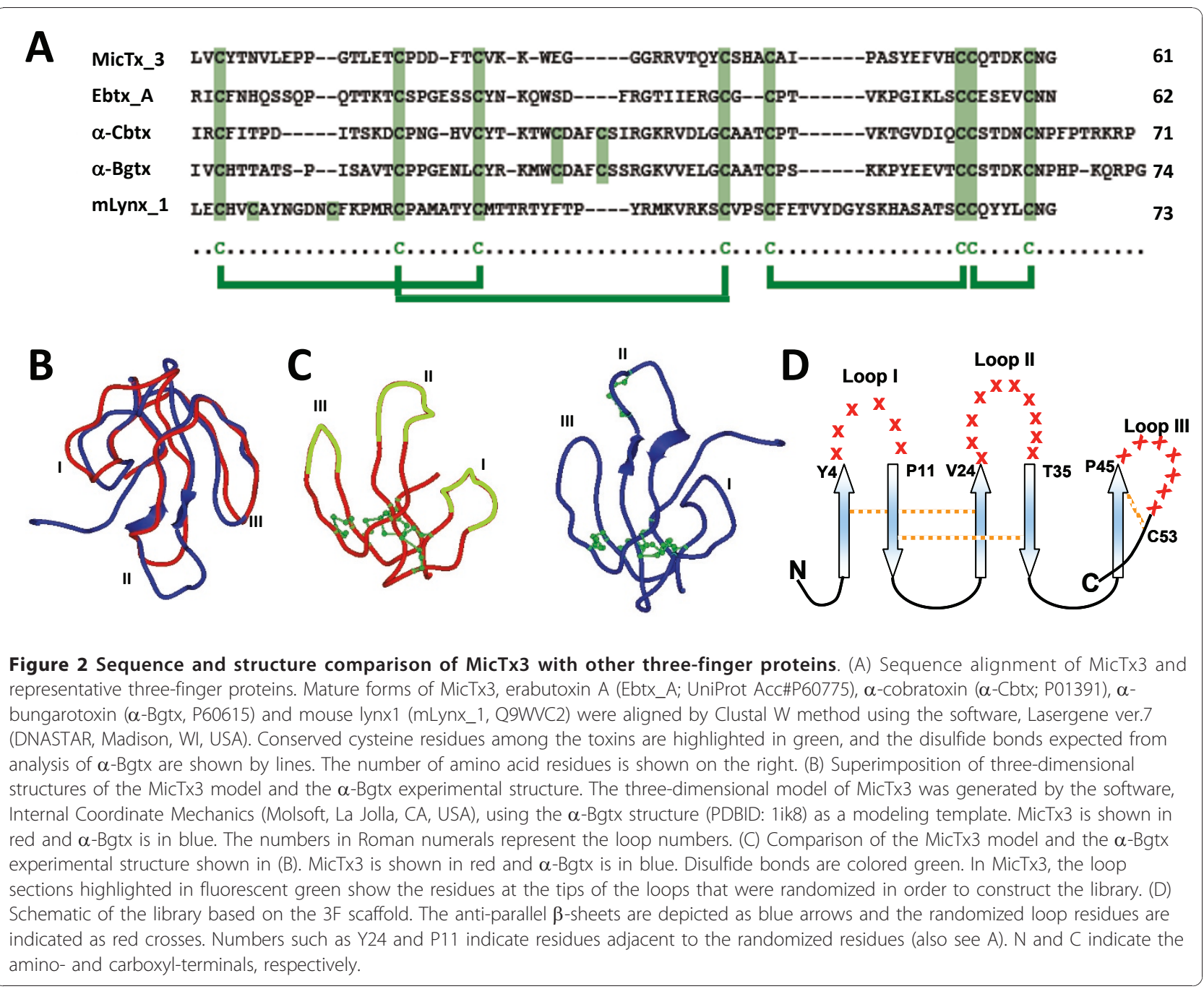

binding molecules by randomization of the loops, followed by screening to identify the binding proteins.

\section{In vitro selection of the $3 \mathrm{~F}$ library}

The potential of the 3F library was assessed by searching the library for novel modulatory molecules of IL-6R. This was performed by affinity selection of binding molecules from the initial library over several rounds during which conditions were progressively made more stringent (see Methods). After 10 rounds of rigorous affinity selection, the DNA pools were cloned and sequenced.

The qualitative binding characteristics of Round 10 library (R10) were analyzed using IL-6R and AChBP (Figure 3A). The R10 displayed proteins showed negligible affinity for non-coated beads but bound significantly to IL-6R, indicating that the R10 library was enriched in comparison with R0, which did not bind to IL-6R. No detectable binding was observed to AChBP. Binding of the $3 \mathrm{~F}$-derived proteins is thus specific to
IL-6R. Reduction of the R10 library with DTT resulted in no binding to any of the proteins tested, indicating that binding takes place via the protein part of the displayed protein (i.e., mRNA-protein) and the protein loop(s) protruded by forming disulfide bridges between cysteine residues may contribute to the specific binding.

Analysis of the sequences revealed that the pool could be majorly divided into 4 groups based on the similarity of the loop sequences (Figure 3B). R10-17-like sequences were $70 \%$ of the total clones, followed by R10-15, R10-13 and R10-14, at 5-10\% each. A few mutations were observed in the constant regions, which could be due to failure of the polymerase proofreading mechanism as the library underwent totally $\sim 650$ cycles of PCR. Point mutations were also observed in the loop sequences, indicating that different amino acid residues may be accommodated in these regions. Silent mutations (different coding sequences expressing the same amino acid) were also observed at some positions. 


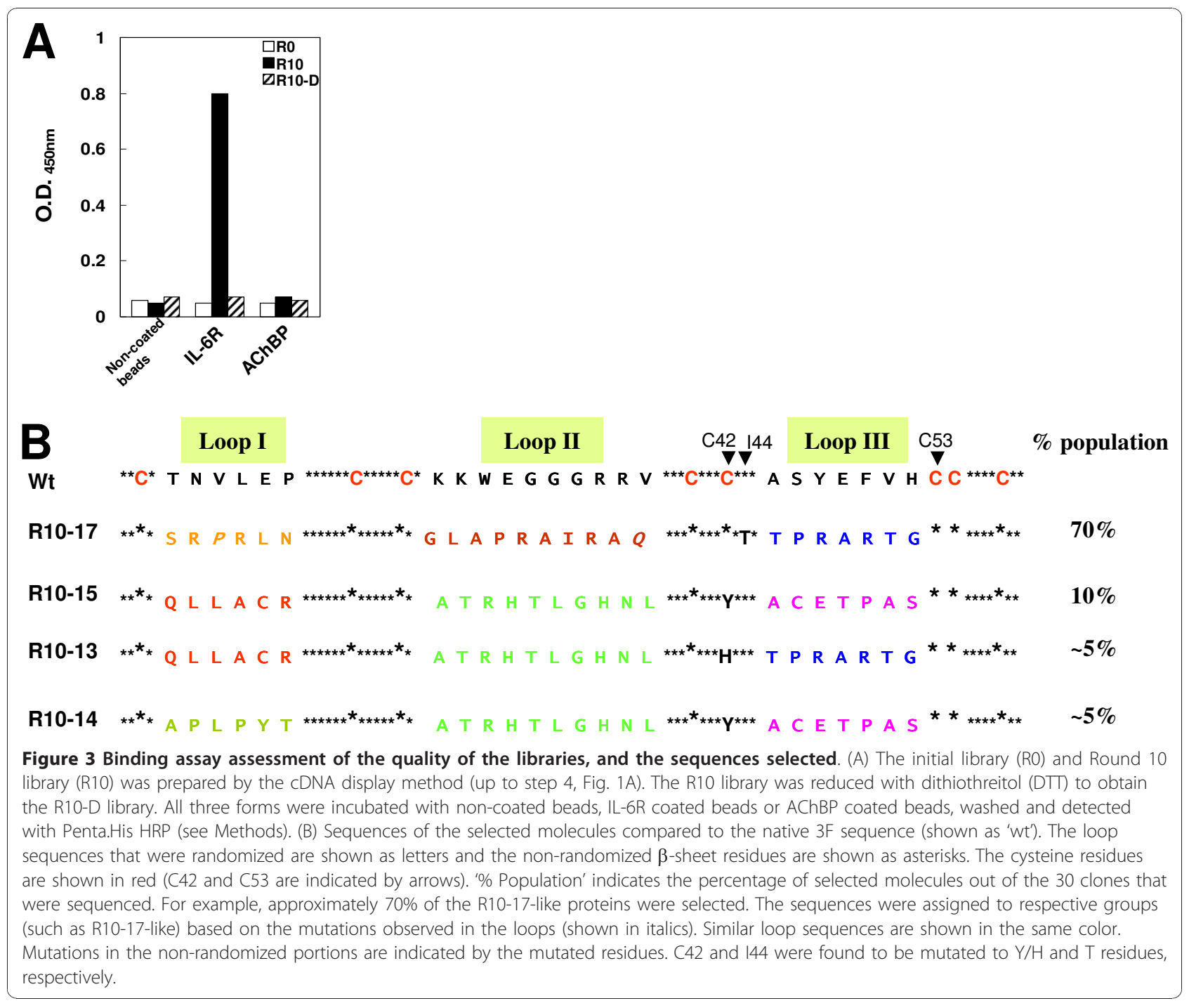

These observations support sequence specific enrichment of sequences from the library. C42, which is supposed to form a disulfide bond with $\mathrm{C} 53$ in the parent $3 \mathrm{~F}$, was found to be mutated to either $\mathrm{Y}$ or $\mathrm{H}$ in $\mathrm{R} 10$ 13,14 and 15 . However, a cysteine residue (C47) was observed in the loop sequences of R10-14 and 15, which were subjected to randomization, so there is the possibility of a disulfide bond between $\mathrm{C} 47$ in the third loop and C53 in the $\beta$-sheet of the scaffold. In R10-13, no cysteine residue was selected either at the $47^{\text {th }}$ position or any of the other randomized positions in the third loop, which could have implications in the folding of the molecule. The cysteine framework was intact in R10-17 which was in majority.

\section{Expression of candidate proteins}

Recombinant proteins were expressed in Escherichia coli by two approaches. In the first, the candidates were fused to the C-terminal of thioredoxin ( $\operatorname{Tr} x$ ) and, in general, more than $50 \%$ of the expressed protein was soluble fraction. In the case of R10-14, more than $80 \%$ soluble protein was observed (Figure 4A). In the second, proteins were expressed without the fusion and were mostly observed in the insoluble fraction. The insoluble proteins were recovered as inclusion bodies, purified and refolded under various conditions (Figure 4B and $4 \mathrm{C}$ ). We found that proteins refolded in the presence of reduced and oxidized glutathione (a redox pair) had random conformation, as judged from their CD spectra (Figure 4C (i)). However, when immobilized protein disulfide isomerase (PDI), a chaperone known to assist and improve folding/refolding [23], was included in the redox buffer, we observed spectra resembling $\beta$ sheets (Figure 4C (ii)). Ellipticities near 200 and $215 \mathrm{~nm}$ (spectra in dotted line) indicate a major $\beta$-sheet conformation [24]. The fusion and refolded proteins were used 


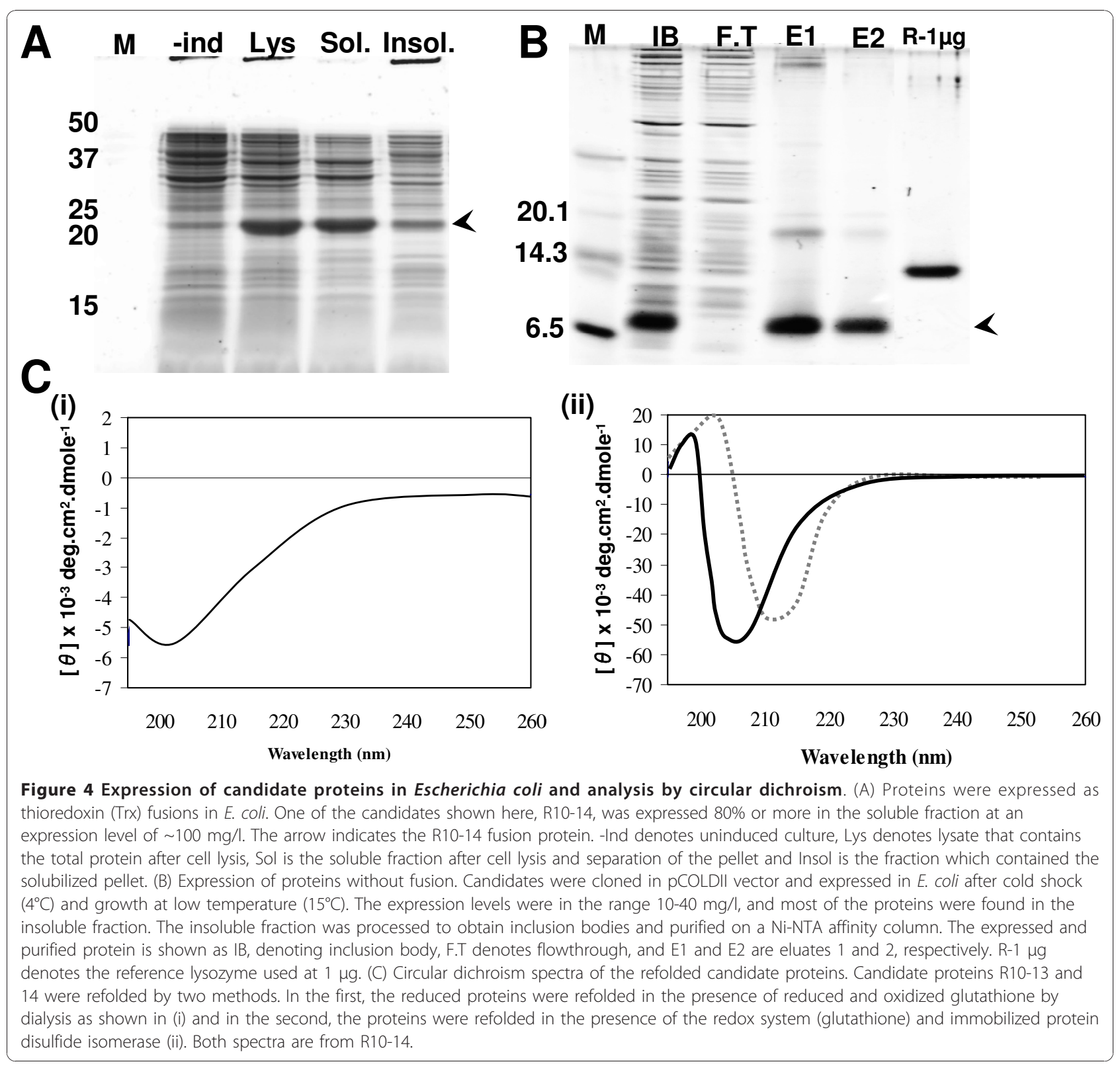

for biochemical assays and only the refolded proteins were used for biological assays.

\section{In vitro biochemical and biological assays}

The dissociation constant $\left(K_{\mathrm{d}}\right)$ was determined by the method described by Friguet et al. [25] with a few modifications. The values were found to be in the $48-115 \mathrm{nM}$ range (Table 1), which are comparable to the dissociation constants of IL-6 $(20 \pm 3$; Table 1$)$.

The ability of the selected proteins to inhibit the interaction of IL- 6 with IL-6R was analyzed by an in vitro biochemical competition assay. We observed that IL-6 inhibited the binding of biotinylated IL-6 to IL-6R with an IC50 value of $80 \pm 3 \mathrm{nM}$, while the values obtained for R10-13, R10-14 and R10-15 were $113 \pm 7,164 \pm 9$ and $102 \pm 13 \mathrm{nM}$, respectively (Table 1 ). R10-17 was found to be non-competitive.

The selected proteins, R10-14 and R10-15, were found to be highly specific to IL-6R, with no apparent affinity for other proteins such as AChBP and IgG (Figure 5A).

Next, we carried out in vitro biological assays using the IL-6-dependent DS-1 human B-lymphoma cell line. As shown in Figure 5B, IL-6R mAb inhibited the IL-6 dependent proliferation of cells in a dose dependent manner (IC50 = $1.2 \pm 0.15 \mathrm{nM}$ ), and R10-13 was found to inhibit the growth of cells $($ IC50 $=1.4 \pm 0.3 \mu \mathrm{M})$. 
Table 1 Characteristics of the selected 3F proteins and their derivative peptides

\begin{tabular}{|c|c|c|c|c|c|c|c|c|}
\hline No. & Name & Sequence $^{1}$ & $\mathrm{aa}^{2}$ & Disulfide & $K_{\mathrm{d}}(\mathrm{nM})^{3}$ & Function $^{4}$ & $\mathrm{IC} 50^{5}(\mathrm{nM})$ & IC50/EC50 $(\mu \mathrm{M})$ \\
\hline 1 & R10-17 & SRPRLN GLAPRAIRAQ TPRARTG & 70 & - & $152 \pm 10$ & NC & $\mathrm{NC}$ & - \\
\hline 2 & R10-15 & QLLACR ATRHTLGHNL ACETPAS & 70 & - & $115 \pm 9$ & $\mathrm{C}$ and $\mathrm{NI}$ & $102 \pm 13$ & $\mathrm{NI}$ \\
\hline 3 & R10-13 & QLLACR ATRHTLGHNL TPRARTG & 70 & - & $48 \pm 8$ & $C$ and $I$ & $113 \pm 7$ & $1.4 \pm 0.3$ \\
\hline 4 & R10-14 & APLPYT ATRHTLGHNL ACETPAS & 70 & - & $55 \pm 6$ & $C$ and $A$ & $164 \pm 9$ & $0.02 \pm 0.006$ \\
\hline 5 & 13-L1 & LVCYQLLASRPGTLETGPDDFTCV & 24 & $\mathrm{C} 3$ and $\mathrm{C} 23$ & ND & 1 & ND & $10 \pm 1.5$ \\
\hline 6 & $13-L 2$ & ETCPDDFTGVATRHTLGHNLTQYCS & 25 & C3 and C24 & ND & $\mathrm{NI}$ & ND & $\mathrm{Nl}$ \\
\hline 7 & $13-L 3$ & ACAIPTPRARTGC & 13 & $\mathrm{C} 2$ and $\mathrm{C} 13$ & ND & $\mathrm{NI}$ & ND & $\mathrm{NI}$ \\
\hline 8 & 14-L1 & LVCYAPLPYTPGTLETGPDDFTCV & 24 & $\mathrm{C} 3$ and C23 & ND & A & ND & $0.03 \pm 0.005$ \\
\hline 9 & 14-L3 & IPACETPASC & 10 & $\mathrm{C} 4$ and $\mathrm{C} 10$ & ND & $\mathrm{NI}$ & ND & $\mathrm{NI}$ \\
\hline
\end{tabular}

${ }^{1}$ Loop sequences of the proteins are for R10-17, 15, 13 and 14. Sequences of individual peptides are shown in full. 13-L1 represents loop 1 of the protein R10-13, bold letters indicate point mutations, and loop sequences are underlined.

${ }^{2}$ The number of residues in the proteins (e.g., 70) includes 61 residues of the protein, spacer GGS and $6 \mathrm{xHis}$.

${ }^{3}$ Affinity was measured by Elisa (25). IL-6 was also assayed and the $K_{d}$ value was found to be $20 \pm 5 \mathrm{nM}$. ND = not determined.

${ }^{4} \mathrm{NC}=$ Non-Competitive, $\mathrm{C}=$ Competitive, $\mathrm{NI}=$ Non-Inhibitory, $\mathrm{I}=$ Inhibitory, $\mathrm{A}=$ Agonist.

${ }^{5}$ IC50 was determined by ELISA. IL- 6 was also assayed and the value was found to be $80 \pm 3 \mathrm{nM}$.

${ }^{6}$ Measured by IL- 6 dependent DS-1 proliferation assay. IC50 = concentration for $50 \%$ growth inhibition, which for monoclonal antibody was determined to be 1.2 $\pm 0.15 \mathrm{nM}$ and $\mathrm{ED} 50=50 \%$ effective concentration, which for IL-6 was found to be $15 \pm 2 \mathrm{pM}$.

The other proteins, R10-15 and 17, showed essentially no effect on the cell growth. However, we observed that R10-14 boosted the proliferation of cells and thus speculated that this molecule could be an agonist of IL-6R. Therefore, we further investigated the potential of R1014 to induce cell proliferation in the absence of IL-6 and found that R10-14 indeed induces proliferation even in the absence of IL-6 and thus acts as an IL-6 mimetic molecule (Figure 5C, (i) and 5C (ii)). The ED50 (50\% effective dose) values were determined to be $15 \pm 2 \mathrm{pM}$ for IL- 6 and $20 \pm 6 \mathrm{nM}$ for R10-14 (Figure 5C and Table 1).

Size optimization of the three-finger scaffold (3F to $1 \mathrm{~F}$ )

Short peptides retaining the essential features of the $3 \mathrm{~F}$ scaffold were generated by size minimization. Peptides were designed that included the sequences of the scaffold forming the $\beta$-sheets, loops and the disulfide bonds of the selected molecules (see Methods). Thus, the resulting peptides resemble one of the fingers (1F) of the three-finger protein (3F) (Figure 6A and Additional file 3, Fig. S2 online).

The potency of the designed peptides was assessed using the biological assay described above. In the case of R10-14 derived peptides, 13-L2 (which is identical to the $2^{\text {nd }}$ finger of R10-14; also see Figure $3 \mathrm{~B}$ ) and 14-L3 were ineffective in inducing cell proliferation. However, 14-L1
$($ ED50 $=30 \pm 5 \mathrm{nM})$ was as effective as the parent molecule, R10-14 (ED50 = $20 \pm 6 \mathrm{nM}$ ), at inducing cell proliferation. Similarly, in the case of R10-13 derived peptides, 13-L2 and 13-L3 could not inhibit cell proliferation, however 13-L1 inhibited cell proliferation (IC50 $=10 \pm 1.5 \mu \mathrm{M})$, albeit with a lower potency than the parent R10-13 (IC50 = 1.4 $\pm 0.3 \mu \mathrm{M})$ (Figure 6B, 6C and Table 1).

\section{Discussion}

Antibodies and its derivatives such as scFv, minibody, diabody and others have been increasingly used for protein engineering and directed evolution due to their high affinity and specificity towards their targets [26]. Recently, however, alternate protein scaffolds that provide potential advantages over antibodies such as smaller size, easier production and optimization, are showing promise and are attracting attention [8,9]. Such scaffolds are comprised of a single polypeptide chain, have defined structure, and contain amenable regions such as loops that resemble the complementary determining regions (CDR) of antibodies. These CDR-like loops can be utilized to generate large libraries that can be used to obtain molecules with completely novel properties.

In this regard, we identified and explored a new scaffold, three-finger (3F), for directed evolution and protein engineering. $3 \mathrm{~F}$ proteins are small, compact, highly 


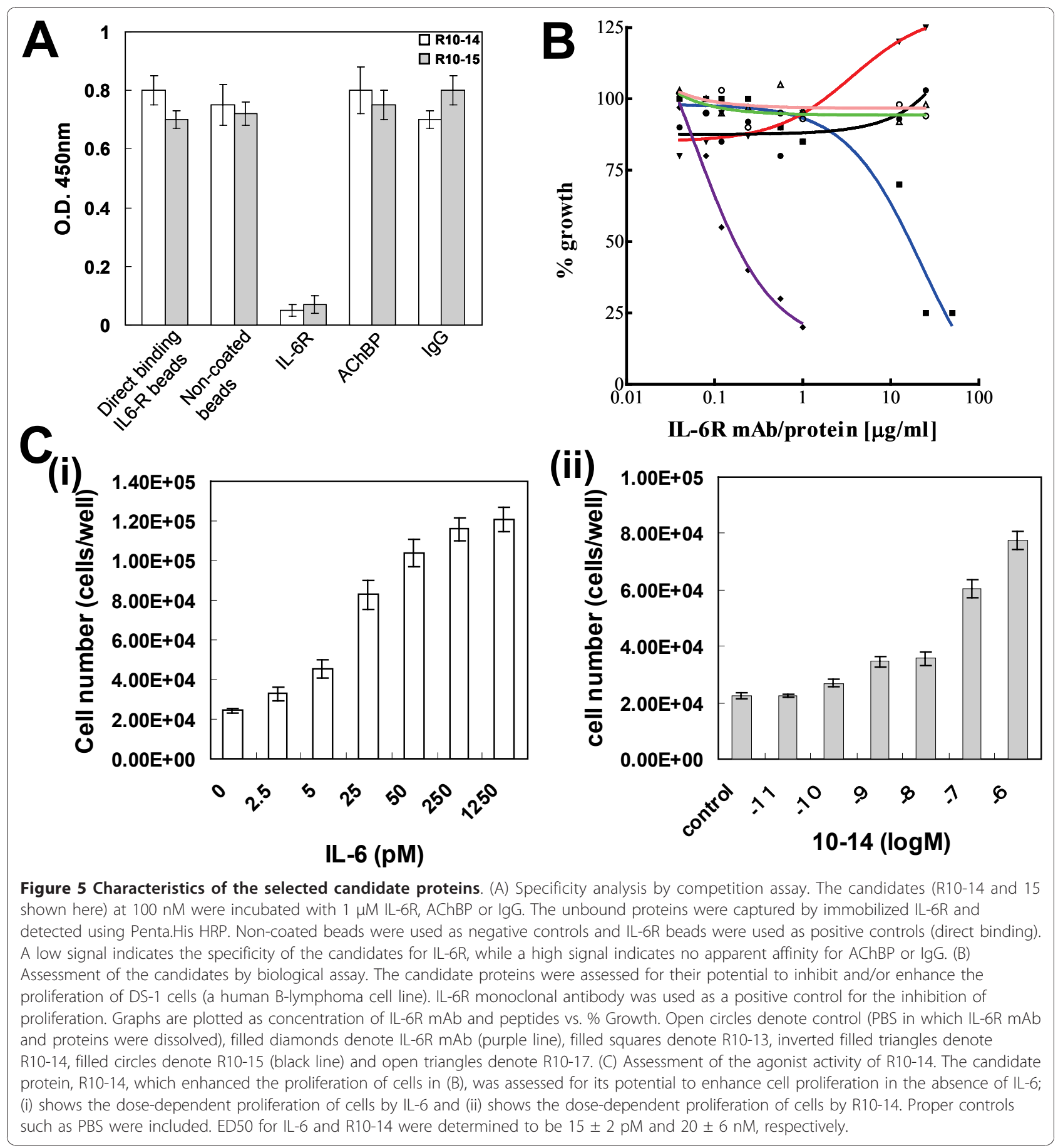

specific, stable to thermal and protease exposure, and are found in a variety of organisms ranging from snakes to humans [10-13]. Furthermore, molecular evolution study revealed that the $3 \mathrm{~F}$ toxin genes show accelerated evolution, by which the gene product could rapidly adapt to the environmental changes including prey species. The evolution rates are significantly higher in the finger regions. These characteristics make them excellent candidates for protein engineering and directed evolution and, thus, potentially useful for research, diagnostic and therapeutic uses. We have utilized cDNA display for the directed evolution of a $3 \mathrm{~F}$ scaffold library to obtain molecules that bind to and possibly regulate interleukin-6 receptor (IL-6R).

cDNA display is based on the formation of a covalent fusion between the expressed protein and puromycin 


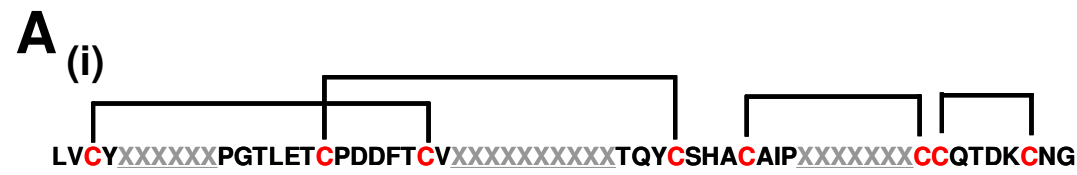

Loop II

\section{Loop III}

$B_{(i)}$

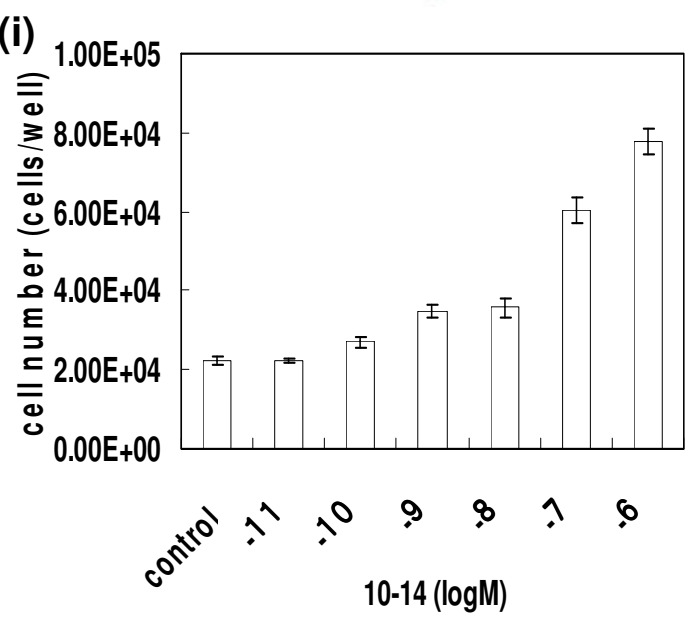

C

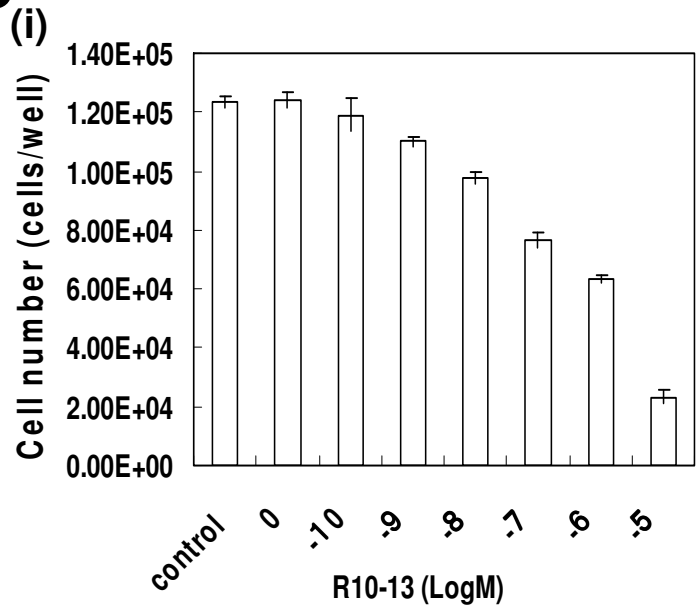

(ii)

(ii) (ii)

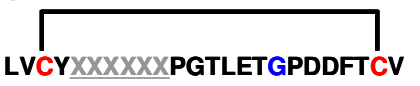

\section{Loop I}

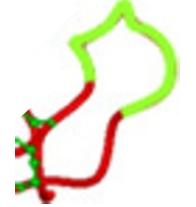

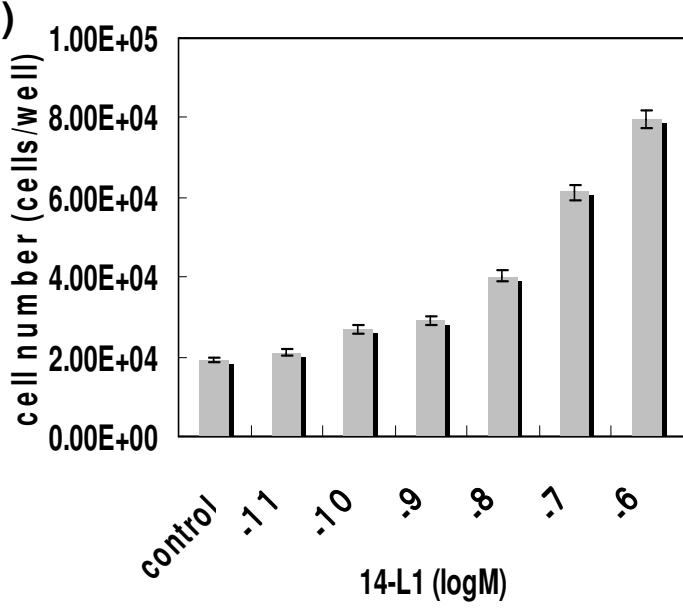

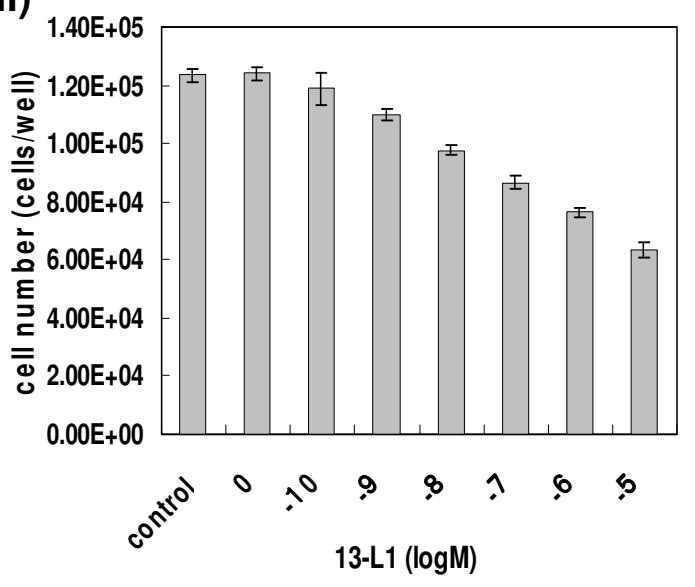

Figure 6 Biological assessment of the size-optimized peptides from the selected candidate proteins. (A) The size optimization strategy was designed to obtain peptides resembling three single fingers between 12-25 residues long (see Additional file 3 Fig. S2) from the parent candidate proteins which are 61 residues long (i). The spatial structures of the parent protein (i) and the derived peptide containing Loop I (ii) are given (disulfide bonds are shown in green and the fluorescent green denotes different loop sequences. (B) Assessment of the peptides as agonists of IL-6R. R10-14 (i) and the designed and chemically synthesized peptides 14-L1 (ii) were assessed for their ability to stimulate the proliferation of DS-1 cells in the absence of IL-6 in a dose-dependent manner. (C) Assessment of the peptides as antagonists. R10-13 (i) and the designed and chemically synthesized peptides 13-L1 (ii) were challenged in the IL-6 dependent proliferation of DS-1 cells in a dose-dependent manner. 
linked to the genotype (cDNA). Briefly, a DNA linker containing puromycin is rapidly ligated to the mRNA. Following protein expression, puromycin forms a covalent fusion with the protein on the stalled ribosome $[4,5]$. This is followed by rapid purification of the complex, facilitated by the biotin-streptavidin pair, and subsequent cDNA synthesis utilizing the 'built-in' primer contained in the linker. Thus, the protein, which is covalently attached to the puromycin-linker, eventually gets linked to the cDNA (Figure 1A) [6]. This process is extremely fast, prevents degradation of the mRNA portion and thus contributes to prepare the library intact in quality and size, which are crucial for the subsequent selection of molecules. The cDNA display technology utilizes a cell-free translation system and, as a result, is capable of generating libraries in the order of $10^{12-14}$, compared to $10^{8}$ in the case of cell-dependent methods such as phage display [3].

Affinity selection of the 3F library aimed at identifying novel molecules binding to IL-6R enriched the library with proteins specific for IL-6R; the sequences of these proteins were divided into different major and minor groups (Figure 3). The selected candidates bound to IL6R with affinity (nanomolar range) and specificity similar to that of antibodies in the biochemical assays. Candidates that competed with the natural ligand, IL-6, were also successfully obtained. Antagonists as well as agonists were identified biologically using an IL-6 dependent cell proliferation assay (Table 1). These results demonstrate the potentials of the 3F scaffold to accommodate residues, different from the parent residues, which are required to generate high-diversity libraries and then to utilize the libraries for obtaining novel ligands for macromolecular targets such as IL-6R by iterative selection. Disulfide-rich proteins such as knottin, tendamistat and others have been shown to be useful as templates to search for protease inhibitiors, however, none have been shown to bind and/or regulate the activity of macromolecular receptors [8]. Our results show for the first time that regulatory molecules against receptors can be obtained by the directed evolution of the $3 F$ scaffold.

The 3F scaffold provides potential advantages over related scaffold proteins that have been successfully used for directed evolution. $3 \mathrm{~F}(\sim 6.7 \mathrm{kDa})$ is smaller than many other proteins such as $\mathrm{scFv}(\sim 30 \mathrm{kDa})$, DARPin $(\sim 20 \mathrm{kDa})$, lipocalin $(\sim 20 \mathrm{kDa})$, fibronectin $(\sim 10 \mathrm{kDa})$ and zinc-finger ( $\sim 9 \mathrm{kDa})$, and is comparable to Affibody $(\sim 6 \mathrm{kDa})$; these proteins have been used for the purpose of directed evolution [9]. The number of residues in the loops that can be utilized for the construction of libraries is around $38 \%$, which is larger than that of published scaffolds such as $\sim 10 \%$ (scFv) [26], 22\% (Affibody) [27], $\sim 22 \%$ (fibronectin) [28], 26\% (zinc-finger) [29], 9\% (lipocalin) [30], 21\% (DARPin) [31], and others. The greater flexibility regarding the residues that can be randomized provides a larger interaction surface between the binding partners during the binding event. The discovery of an agonist in the 3F library also demonstrates the utility of this approach, particularly from the viewpoint that agonists have been identified from immunoglobulin sources [32-34] and random peptide libraries $[35,36]$, but there are no published reports of agonistic molecules from non-immunoglobulin proteins [9]. The high affinity and remarkable specificity of $3 \mathrm{~F}$ proteins for their targets, along with their stability, make this scaffold suitable for diagnostic, therapeutic and protein chip purposes. Furthermore, the presence of a single lysine (K58) near the $\mathrm{C}$-terminus in the $3 \mathrm{~F}$ molecule used in this study will facilitate homogeneous labeling of the 3F proteins with chemical moieties such as fluorescein, biotin and other labels and probes that can be exploited for research and diagnostic purposes (e.g., fluorescence imaging of tumors, protein chips, ELISA).

When the candidate proteins were expressed in E. coli as recombinant proteins in fusion with thioredoxin, more than $50 \%$ of the expressed proteins were found in the soluble fraction; one of the candidates, R10-14, showed more than $80 \%$ soluble protein (Figure $4 \mathrm{~A}$ ). Similarly, the candidates also expressed well at $1-2 \mathrm{mg} / \mathrm{ml}$ of cell-free lysate when produced as maltose binding protein fusions in a bacterial cell-free translation system such as RTS (Roche, Penzberg, Germany), with nearly all of the protein present in the soluble fraction and checked for their binding activities for IL-6R (data not shown). In contrast, disulfide-rich proteins are known to be poorly expressed in the native form in bacteria, and generally tend to form inclusion bodies [37]. In an attempt to produce nonfusion proteins in bacteria, we observed that the proteins aggregated as inclusion bodies (Figure 4B). However, by using a refolding system that included the redox buffer and immobilized protein disulfide isomerase, the proteins seem to be refolded from the analysis of circular dichroism (Figure 4C). Further, 3F proteins can also be successfully produced in the native state using Pichia pastoris as the host system [38].

The 3F proteins are leaf-like, flat molecules with the three fingers extending from a globular head $[39,40]$. Taking advantage of this structure, we designed a strategy to minimize the size of selected $3 \mathrm{~F}$ proteins into three, single finger peptides, which lead to three interesting results. First, the size was successfully reduced to 24 residues compared to 61 residues in the parent $3 \mathrm{~F}$, and thus can be conveniently prepared by chemically synthesis and facilitate molecular dynamic studies; second, we identified the effector fingers which retained activity; third, function was observed in the $1^{\text {st }}$ finger, $i$. e., 13-L1 and 14-L1 (Table 1). 
Scaffolds based on single-chain repeat proteins such as DARPins and avimers have been successfully moderated in size (reduced or increased) due to the modular nature of parent proteins $[31,41]$, however, there are no reports of other single-chain proteins, such as fibronectin, lipocalins and affibodies, being successfully reduced in size. The possibility of further size reduction of monomers in DARPins (the monomer consists of 33 residues) and avimers (a monomer containing 35 residues) has also not been investigated. Therefore, we believe that this is the first report of the successful reduction of a single-chain $3 F$ scaffold to shorter peptides of only 24 residues which retain activity comparable to that of the parent protein. Recently, $\sim 3 \mathrm{kDa}$ peptides derived by rational design from $\mathrm{V}_{\mathrm{H}}$ (complementarity region) and $\mathrm{V}_{\mathrm{L}}$ (framework region) domains of Fab have been shown to mimic the parent antibody [42]. Encouraged by these results, the concept of single finger libraries will be interesting to pursue and might be more attractive.

IL-6 is a pleiotropic cytokine involved in the regulation of cell growth, differentiation and various other cellular functions [17], and is known to play a role in the pathogenesis of a variety of diseases [18,20,43-46] and in brain injury $[47,48]$. Therefore, both antagonist and agonist molecules that can regulate the IL-6R-mediated signaling of IL-6 are important for research, diagnostic and therapeutic purposes. An antibody that acts as an antagonist of IL-6R has been reported [49]; however, there are no reports of agonists of IL-6R. The present study generated R10-13, which has a size $1 / 20^{\text {th }}$ that of an antibody and an IC50 of $9.8 \mu \mathrm{g} / \mathrm{ml}($ IC50 $=0.18 \mu \mathrm{g} /$ $\mathrm{ml}$ of $\mathrm{mAb}$, as determined in this study), and also 13L1, which has a size $1 / 57^{\text {th }}$ that of an antibody, and an IC50 $=26 \mu \mathrm{g} / \mathrm{ml}$. In different reports, IC50 values for peptides selected by phage display and rational design were reported in the range $25-60 \mu \mathrm{g} / \mathrm{ml}[50,51]$. 3F derived peptides are, therefore, potentially capable of inhibiting the IL-6R-mediated signaling. R10-14 (ED50 $=140 \mathrm{ng} / \mathrm{ml})$ and $14-\mathrm{L} 1$ (ED50 = $79 \mathrm{ng} / \mathrm{ml})$ can potentially be developed and used as agonists of IL-6R (ED50 $=0.5 \mathrm{ng} / \mathrm{ml}$ of IL- 6 as determined by this assay) either to supplement IL-6, or used when IL- 6 is deficient.

It is noteworthy that the directed evolution of $3 \mathrm{~F}$ library which was carried out using the soluble extracellular IL-6R generated molecules having comparable affinity and competitive potential to IL-6 (Table 1). However, in cellular assays the peptides were found to be less potent either as antagonist or agonist compared to IL-6R mAb and IL-6 showing approximately 100 times lesser activity. The antagonist and agonist molecules developed in this study, however, have comparable or better efficacy than those previously reported. Martin et al. obtained a clone from affibody library with an affinity in the micromolar range and antagonist function [52], Su et al. [50] and Feng et al. [51] reported peptides with IC50 in the range 25-60 $\mu \mathrm{g} / \mathrm{ml}$. Further, phage display based selections of constrained cyclic libraries have been reported to generate agonists in the micromolar range $[35,36]$. The above peptides and proteins obtained in this study may be regarded as lead molecules from the viewpoint of potency, which can be increased further by exploiting affinity maturation of the parent $3 F$ candidates $[53,54]$ optimization by dimerization or multimerization of the peptides [55-57], and other approaches. These lead molecules were generated by directed evolution of a $3 \mathrm{~F}$ protein library. Therefore, $3 \mathrm{~F}$ library used in this study provides a platform to obtain regulatory molecules of IL- 6 receptor and, in principle, other macromolecules.

In analogy to 3F scaffold, other peptide scaffolds originating from accelerated evolution such as inhibitor cysteine knot may also be utilized as templates for random peptide libraries.

\section{Conclusions}

We have constructed a high diversity library utilizing $3 F$ scaffold as a template and randomizing the loops with which the parent molecule binds to its natural receptor. This library was screened against soluble extracellular IL-6R and yielded ligand molecules that bind with high affinity to the receptor comparable to IL-6. These ligands have both antagonist and agonist function as revealed in a cellular assay. We have also successfully achieved size reduction of this single chain scaffold into single fingers without significant loss of activity. Therefore, 3F proteins are promising candidates for protein engineering, and directed evolution can be used to generate molecules for research, diagnostic and therapeutic uses.

\section{Methods}

\section{Preparation of the three-finger library}

A full construct for preparing the three-finger (3F) protein library was designed to facilitate the formation and purification of cDNA displayed proteins. The $3 \mathrm{~F}$ genetic construct was prepared by joining the fragments by overlap PCR (see Additional file 2, Table S1 and Additional file 1, Fig. S1 online). Briefly, to the sequence of the $3 F$ library, SP6 fragment containing the SP6 promoter, cap site, Xenopus globin untranslated sequence (UTR) and translation initiation site was added at the 5 ' end, while the $\left(\mathrm{G}_{3}-\mathrm{S}\right)_{2}$ spacer, C-terminal $6 \mathrm{xHis},\left(\mathrm{G}_{3}-\mathrm{S}\right)$ spacer and Y-tag sequences were added at the 3 ' end (Additional file 1, Fig. S1). The final library was expressed and purified by Ni-NTA agarose (Qiagen, Valencia, CA, USA) and the library's quality was assessed by sequencing 20 clones 
picked at random after cloning them into the TA cloning vector (Invitrogen, Carlsbad, CA, USA).

\section{Transcription of library DNAs}

The above library DNAs were subjected to polyacrylamide gel electrophoresis (PAGE), purified from the gel, and then annealed by heating at $94^{\circ} \mathrm{C}$ and gradient cooling to form the correctly paired double-stranded DNA. The template DNAs were transcribed by SP6 RNA polymerase in a RiboMAX Large Scale Production Systems (Promega, Madison, WI, USA). Reactions were terminated by adding DNase I and products were purified using the phenol/chloroform method. RNA concentration was measured by a spectrophotometer at $260 \mathrm{~nm}$.

\section{Synthesis of the puromycin-linker}

The puromycin-linker was synthesized, as described previously [6], by cross-linking two modified oligonucleotides with the hetero-bifunctional reagent, EMCS (N-(6-maleimidocaproyloxy) succinimide) (Figure 1B).

The modified oligonucleotides, Puro-F-S [5'-(S)-TC (F)-(Spec18)-(Spec18)-(Spec18)-(Spec18)-CC-(Puro)-3'] and Biotin-loop [5'-CCCGGTGCAGCTGTTTCATC (T-B) CGGAAACAGCTGCACCCCCCGCCGCCCCCCG (T)CCT-3'] were custom synthesized (BEX Co., Tokyo, Japan). The symbol (S) denotes 5'-thiol-modifier C6, (F), fluorescein-dT; (Puro), puromycin CPG; (Spec18), spacer phosphoramidite 18; (T), amino-modifier C6 dT; (T-B), biotin-dT. The underlined sequence indicates the cutting site of restriction enzyme $P v u I I)$ All phosphoramidite reagents used for modifications were from Glen Research (Sterling, VA, USA).

\section{Ligation of mRNA to the linker}

mRNA was annealed to the biotinylated puromycinlinker DNA (1:1 ratio) via the Y-tag sequence in $1 \times$ ligase buffer (Takara, Kyoto, Japan) by heating at $94^{\circ} \mathrm{C}$ and cooling slowly. mRNA and linker were ligated by the addition of $\mathrm{T} 4$ kinase $(3 \mathrm{U})$ and T4 RNA ligase (20 $\mathrm{U})$ (Takara) at $25^{\circ} \mathrm{C}$ for $1 \mathrm{~h}$, then the conjugated product was purified using an RNeasy Kit (Qiagen). Ligation efficiency and the purity of the products were checked by polyacrylamide gel electrophoresis using FITC and/or VistraGreen (Molecular Probes, USA) staining on a fluoroimager (Bio-Rad, Hercules, CA, USA).

\section{CDNA display}

mRNA-puromycin linker DNA (3-5 picomoles) was translated in $25 \mu \mathrm{l}$ using a Rectic Lysate IVT Kit (Ambion, Austin, TX, USA) at $30^{\circ} \mathrm{C}$ for $10 \mathrm{~min}$. After translation, proteins were covalently linked to the puromycin linker in the presence of $65 \mathrm{mM} \mathrm{MgCl}_{2}$ and
$750 \mathrm{mM} \mathrm{KCl}$ at $37^{\circ} \mathrm{C}$ for $2 \mathrm{~h}$. Purification was achieved using the biotin-streptavidin interaction for 10-15 min., followed by M-MLV reverse transcriptase (Takara) reaction to form the cDNA/mRNA hybrid utilizing the 'built-in' primer included in the linker (Figure 1B). Displayed proteins were released from the biotin-streptavidin complex upon digestion with $12 \mathrm{U}$ of $P v u I I$ restriction enzyme in the supplied buffer at $37^{\circ} \mathrm{C}$ for $1 \mathrm{~h}$. Full length displayed proteins were purified utilizing the $\mathrm{C}$-terminal $6 x$ His-tag by Ni-NTA magnetic beads (Qiagen). The purified display proteins were quantified by fluorescence using a Beacon 2000 (Panvera, WI, USA) and a known FITC-labeled DNA as standard.

The whole process was scaled up for library preparation where 200 pmols was used for translation; the subsequent rounds were reduced to $1 / 5^{\text {th }}$ for R2-R5 and $1 /$ $10^{\text {th }}$ for R6-R10.

\section{Library quality assessment}

The affinity of the initial 3F library (R0) was checked by a binding assay for immobilized IL-6R and AChBP (see immobilization procedures in the next section). Equal amounts of $3 \mathrm{~F}$ library prepared by cDNA display (up to step 4, Figure 1A) were incubated with non-coated beads, $250 \mathrm{nM}$ IL-6R or AChBP coated beads for $1 \mathrm{~h}$ at room temperature in PBS. Each mixture was washed with PBS-T (0.1\% Tween) and subsequently incubated with Penta.His-HRP (Qiagen) in PBS-T for $30 \mathrm{~min}$. at $25^{\circ} \mathrm{C}$. The mixtures were washed several times with PBS-T followed by the addition of substrate, 3, 3', 5, 5'Tetramethylbenzidine (TMB; Sigma, Saint Louis, USA). After color development was complete, the reaction was stopped by the addition of $0.5 \mathrm{M} \mathrm{H}_{2} \mathrm{SO}_{4}$, each mixture was centrifuged, and absorbance was measured at 450 nm.

\section{Preparation of immobilized proteins}

Extracellular IL-6R (PeproTech, London, UK), AChBP (cDNA was cloned from Aplysia kurodai [manuscript in preparation] and the recombinant protein was expressed in E. coli and purified in our laboratory), IgG (human immunoglobulin; Sigma) and BSA (Ambion) were immobilized on NHS-activated Sepharose 4 Fast Flow (Amersham Biosciences) utilizing the amine coupling chemistries to form a chemically stable amide bond according to manufacturer's instructions. Coupling efficiency was estimated by absorbance measurements of initial and unbound protein at $280 \mathrm{~nm}$. The activity of the immobilized proteins (except for BSA) was measured by ELISA using either biotinylated or 6xHis containing ligands. Non-coated beads were also prepared by the same derivatization procedure, but in the absence of protein. 


\section{Selection of IL-6R binders}

The above $3 F$ library was screened to identify molecules selectively binding to IL-6R. Each round of selection was performed with the non-coated beads and IL$6 \mathrm{R}$ coated beads in a batch-selection mode using Phosphate Buffered Saline (PBS) containing an additional $100 \mathrm{mM} \mathrm{NaCl}$ and $0.1 \%$ Tween-20. The initial round contained 2 nM cDNA displayed protein and $300 \mathrm{nM}$ IL-6R. Prior to the selection of IL-6R binders, non-specific Sepharose binders were excluded by preincubation of the library with non-coated beads for $1 \mathrm{~h}$. This was followed by incubation of this precleared library with IL-6R coated beads for $1 \mathrm{~h}$. After incubation, the IL-6R beads were washed several times with the $\mathrm{PBS} / \mathrm{NaCl} /$ Tween-20 buffer and eluted with the same buffer containing $100 \mathrm{mM}$ DTT (dithiothreitol, Sigma). The eluted products were desalted and PCR amplified (conditions described above) with PCR forward and reverse primers (see Additional file 2, Table S1 online), purified and used as templates for PCR amplification with the SP6 fragment. The DNAs were gel purified, transcribed, mRNA ligated to puromycin linker, translated, transformed into display proteins, reverse transcribed, Ni-NTA affinity purified, quantified and used for the next round of selection. The concentration of IL-6R and the incubation time were gradually reduced from $300 \mathrm{nM}$ to $30 \mathrm{nM}$ and from $1 \mathrm{~h}$ to $15 \mathrm{~min}$, respectively, while the number of washes increased progressively during further rounds of selection in order to apply selection pressure. In round 9 and 10, $30 \mathrm{nM}$ biotinylated IL-6R was used.

After 10 rounds of stringent selection the eluted pool was PCR amplified, cloned into TA cloning vector (Invitrogen) and sequenced.

\section{Assessment of the selection}

Direct binding analysis using displayed proteins: Selected Round 10 library (R10) was prepared by the cDNA display method (up to step 4 of Figure 1A) and purified by spin columns (Bio-Rad). One of the fractions was denatured by treatment with $100 \mathrm{mM}$ dithiothreitol (DTT) for $1 \mathrm{~h}$ and purified (designated as R10-D).

Purified display proteins (R10 and R10-D; $5 \mu \mathrm{l}$ ) were mixed with non-coated beads and $250 \mathrm{nM}$ of IL-6R or AChBP coated beads in PBS-BSA (0.01\% BSA) and incubated at $25^{\circ} \mathrm{C}$ for $1 \mathrm{~h}$. The mixtures were washed with PBS-T (0.1\% Tween) and subsequently incubated with Penta.His-HRP (Qiagen) in PBS-T for $30 \mathrm{~min}$. at $25^{\circ} \mathrm{C}$. The mixtures were then washed several times with PBS$\mathrm{T}$ followed by addition of the substrate, 3, 3', 5, 5'-tetramethylbenzidine (TMB; Sigma). After color development was complete, the reaction was stopped by the addition of $\mathrm{H}_{2} \mathrm{SO}_{4}$, the sample was centrifuged, and absorbance measured at $450 \mathrm{~nm}$.

\section{Protein preparation}

Proteins were prepared as thioredoxin fusions using the pBAD/TOPO Thiofusion expression Kit (Invitrogen). Thioredoxin (Trx) was also prepared for control experiments. The selected candidates were PCR amplified (encoding C-terminal 6xHis), cloned into $\mathrm{pBAD} / \mathrm{TOPO}$ Thiofusion expression vector and transformed according to the manufacturer's instructions. Frames were analyzed by sequencing.

The positive clones were cultured in Luria-Bertani (LB) medium containing $50 \mu \mathrm{g} / \mathrm{ml}$ ampicillin at $37^{\circ} \mathrm{C}$ for $16 \mathrm{~h}$. A small portion of the culture was transferred to fresh LB-ampicillin medium and grown to an O.D. of 0.5 at $600 \mathrm{~nm}$, then the culture was induced with $0.02 \%$ arabinose for $4 \mathrm{~h}$ at $37^{\circ} \mathrm{C}$. The cells were harvested by centrifugation at $3000 \mathrm{rpm}$ for $20 \mathrm{~min}$ and lysed with Bugbuster Protein Extraction Reagent (Novagen, San Diego, USA) in the presence of $1 \mu \mathrm{g} / \mathrm{ml}$ DNase, $1 \mu \mathrm{g} / \mathrm{ml}$ RNase and protease inhibitor cocktail (Sigma) at $25^{\circ} \mathrm{C}$ for $20-30 \mathrm{~min}$. The lysate was centrifuged and separated into supernatant (soluble fraction) and pellet (insoluble fraction) and analyzed on SDSPAGE. The soluble fraction was purified by Ni-NTA (Qiagen) affinity for the 6xHis tag of the expressed peptide under native conditions to near homogeneity. Proteins were also confirmed by Western blotting for 6xHis by Penta.His HRP (Qiagen). Protein concentration was measured using a Bio-Rad Protein Assay Kit (Bio-Rad) with bovine serum albumin (BSA) as a standard, and by densitometry measurements of the protein bands on SDS-PAGE gels using known protein concentration standards such as Trx.

Non-fusion proteins were prepared by cloning the candidates in pCOLDII vector (Takara). The plasmids were transformed into Rosetta-gami (DE3) pLacI (Novagen). For expression, colonies were grown in LB medium containing $50 \mu \mathrm{g} / \mathrm{ml}$ ampicillin at $37^{\circ} \mathrm{C}$ for $16 \mathrm{~h}$. A small portion of the culture was added to fresh LBampicillin medium and grown to an O.D. of 0.5 at $600 \mathrm{~nm}$. The culture was incubated at $4^{\circ} \mathrm{C}$ for $30 \mathrm{~min}$. and induced with $0.1 \mathrm{mM}$ IPTG for $15 \mathrm{~h}$ at $15^{\circ} \mathrm{C}$. The cells were harvested by centrifugation at $3000 \mathrm{rpm}$ for 20 min and lysed with Bugbuster Protein Extraction Reagent in the presence of $1 \mu \mathrm{g} / \mathrm{ml}$ DNase, $1 \mu \mathrm{g} / \mathrm{ml}$ RNase and protease inhibitor cocktail at $25^{\circ} \mathrm{C}$ for $20-30$ min. The lysate was centrifuged and separated into soluble and insoluble fractions. The insoluble fraction was purified to provide inclusion bodies, dissolved in buffer containing 50 mM CAPS, pH 11.0, 0.3\% N-lauroylsarcosine and $0.1 \% \beta$-mercaptoethanol (Sigma), purified on a Ni-NTA affinity column under denaturing conditions to near homogeneity, analyzed on tricine-PAGE and confirmed by Western blotting for 6xHis. Lysozyme was used as a concentration reference. 
The denatured proteins were refolded in the presence of $1 \mathrm{mM}$ oxidized glutathione and $10 \mathrm{mM}$ reduced glutathione (Sigma). The proteins were also refolded under identical redox conditions in the presence of immobilized protein disulfide isomerase (PDI; Takara) at a ratio equimolar to the soluble protein. Protein concentration was measured with a Bio-Rad Protein Assay Kit (BioRad) using bovine serum albumin (BSA) as a standard and/or by densitometry of protein bands on tricinePAGE gels with known protein concentration standards such as lysozyme.

Proteins refolded under both conditions were analyzed by circular dichroism spectroscopy on a Jasco J-805 spectropolarimeter. Proteins were prepared in PBS at $0.3-0.5 \mathrm{mg} / \mathrm{ml}$ and measurements taken at $25^{\circ} \mathrm{C}$ from 195-260 nm.

\section{Binding and inhibition assays}

1. Binding assay for dissociation constant $\left(K_{\mathrm{d}}\right)$

Binding affinity of the proteins was assayed as described by Friguet et al. [25] with several modifications. A constant amount of protein (10-25 nM) was incubated with varying amounts of IL-6R ( $1 \mathrm{nM}-1 \mu \mathrm{M})$ in PBS-BSA $(0.01 \% \mathrm{BSA})$ at $25^{\circ} \mathrm{C}$ for $1 \mathrm{~h}$. Proper controls were included. The mixture was applied to a constant amount of IL-6R coated beads (200 nM) and incubated further for $30 \mathrm{~min}$. After several washings with PBS-T (Tween-20, 0.1\%), streptavidin horseradish peroxidase (SA-HRP; Amersham Biosciences) at 1/2000 dilution or Penta.His-HRP (Qiagen) at 1/1000 dilution was added and incubated for $30 \mathrm{~min}-1 \mathrm{~h}$. The supernatant was removed and the beads were washed 4-5 times with PBS-T. TMB substrate $(200 \mu \mathrm{l})$ was added for color development and the reaction was stopped with $0.5 \mathrm{M} \mathrm{H}_{2} \mathrm{SO}_{4}$. Absorbance was monitored at $450 \mathrm{~nm}$. Data were plotted using GraphPad Prism 4 (GraphPad Software Inc., San Diego, CA, USA).

2. Inhibition assay for IC50

Inhibition of the IL-6/IL-6R interaction by the proteins was assayed by competitive inhibition experiments. A fixed amount of biotinylated IL-6 (45 nM, i.e., 3 times the $K_{\mathrm{d}}$ ) and varying amounts of protein/peptide (1 $\mathrm{nM}-2 \mu \mathrm{M})$ were incubated with a constant amount of IL-6R coated beads (350 nM) in PBS-BSA at $25^{\circ} \mathrm{C}$ for 1 h. After several washings with PBS-T, SA-HRP at $1 /$ 2000 dilution was added and incubated for $30 \mathrm{~min}$. The supernatant was removed and the beads were washed 45 times with PBS-T. TMB substrate $(200 \mu \mathrm{l})$ was added for color development, the reaction was stopped with $0.5 \mathrm{M} \mathrm{H}_{2} \mathrm{SO}_{4}$ and absorbance was monitored at $450 \mathrm{~nm}$. Data were plotted using GraphPad Prism 4 (GraphPad Software Inc.).

3. Specificity assay
$100 \mathrm{nM}$ of proteins was incubated with $1 \mu \mathrm{M}$ of various soluble proteins (IL-6R, AChBP or IgG) at RT for 1 $\mathrm{h}$. The mixtures were further incubated with $300 \mathrm{nM}$ of IL-6R coated beads for $1 \mathrm{~h}$. The subsequent procedures were as described for the binding assay.

\section{Design of minimized peptides}

Short cyclic peptides were designed based on the structure and disulfide pattern of $3 \mathrm{~F}$ proteins. The sequences of the peptides are shown in Table-1. The highly conserved disulfide bonds in $3 \mathrm{~F}$ proteins are $\mathrm{C} 1-\mathrm{C} 3, \mathrm{C} 2-\mathrm{C} 4$, C5-C6 and C7-C8 (numbered according to the position of the cysteine residues going from the $\mathrm{N}$ to the $\mathrm{C}$ terminus) [10]. Therefore, we designed cyclic peptides containing the individual loops sequences between $\mathrm{C} 1-\mathrm{C} 3$ (24 residues) where C2 was changed to G, C2-C4 (25 residues) where $\mathrm{C} 3$ was changed to $\mathrm{G}$ and C5-C6 (13 and 10 residues), respectively. If a cysteine was in the loop sequence selected from the library, it was replaced by serine (13-L1). In the case of 14-L3, due to mutation of the $\mathrm{C} 5$ residue, a disulfide bond was formed between the cysteine residue in the loop and C6. All the peptides were synthesized and purified by (Invitrogen, Tokyo, Japan).

\section{Cellular assay}

Cell culture and reagents: The lymphoblast cell line DS1 was obtained from the American Type Culture Collection (CRL-11102; Manassas, USA), and were cultured in RPMI 1640 complete culture medium (Gibco, New York, USA) supplemented with $10 \%$ fetal bovine serum (FBS; Gibco), 10 mM HEPES buffer (Gibco), $10 \mathrm{U} / \mathrm{ml}$ human IL-6 (Sigma, USA), penicillin (16 mg/l) and streptomycin $(25 \mathrm{mg} / \mathrm{l})$ at $37^{\circ} \mathrm{C}$ in a humidified incubator with $5 \% \mathrm{CO}_{2}$ [58]. The cells were routinely passaged every 2 or 3 days in $35 \mathrm{~mm}$ flask (Falcon, Akasaka, Japan). Cells were continuously cultured until harvest for analysis.

Analysis of cell proliferation: Logarithmic growing DS1 cells were dispersed with pipetting, centrifuged at $3000 \mathrm{rpm}$ for $5 \mathrm{~min}$, washed two times in phosphate buffer saline, and were finally resuspended in standard culture medium without IL-6. Prior to the assay, the DS- 1 cells $\left(\sim 2 \times 10^{4}\right.$ cells $\left./ \mathrm{ml}\right)$ were cultured for $24 \mathrm{~h}$ in triplicate in 24 well, flat-bottomed microtiter plates (Falcon) in $1 \mathrm{ml}$ of culture medium. The candidate peptides, IL-6 and anti-human IL-6R antibody (R \& D Systems, Minneapolis, USA) were prepared in standard medium at desired concentration. After $24 \mathrm{~h}$ pre-cultivation, cells were treated with IL-6 $(10 \mathrm{U} / \mathrm{ml})$ and specific antibody $(0.03-2 \mu \mathrm{g} / \mathrm{ml})$, protein or peptide $\left(10^{-10}-10^{-5} \mathrm{M}\right)$ for $48 \mathrm{~h}$, and then the cells were counted under an inverted microscope (Olympus, Hatagaya, Japan). 


\section{Additional material}

Additional file 1: Construction of the three-finger library. (A) Primary structure of the three-finger protein, MicTx3, used in this study. The four disulfide bonds formed between $\mathrm{C} 1-\mathrm{C} 3, \mathrm{C} 2-\mathrm{C} 4, \mathrm{C} 5-\mathrm{C} 6$ and $\mathrm{C} 7-\mathrm{C} 8$ are conserved among the three-finger proteins across a wide variety of species. The loops are shown in color and were randomized to generate the libraries. (B) Genetic construct adopted for CDNA display. SP6 contains the sp6 promoter, capping site and Xenopus globin untranslated sequence (UTR). ATG is the translation initiation codon. The $3 \mathrm{~F}$ gene with the three randomized loops provides the basis of the library. G3S is spacer, 6XHis facilitates affinity purification by Ni-NTA, and Y-tag facilitates ligation of mRNA to the puromycin linker which contains the complementary Y-tag sequence. (C) Construction of library by overlap PCR. (i) The library was constructed by joining the fragments listed in supplementary Table-1 using overlap PCR in various steps. The portions marked in orange denote the randomized residues. (ii) Analysis of the PCR products by electrophoresis. The bands denote the respective fragments. (D) Direct sequencing of the PCR products of the library. The portions shown by arrows represent loops that were randomized. The peaks are smaller than normal due to the presence of a mixture of residues.

\section{Additional file 2: List of oligonucleotides used for library}

preparation and amplification. Oligonucleotides that were used in the preparation of $3 \mathrm{~F}$ library and the primers required for amplification of the selected library are listed.

Additional file 3: Design of shorter peptides containing disulfide bonds from the parent 3F. (A) Scheme for designing peptides. 3F is a leaf-like flat molecule with the three fingers extending from the globular head. The three fingers were designed to split into three individual fingers. (B) Design of the peptides. Primary sequence of the three-finger protein. The four disulfide bonds are formed between C1-C3, C2-C4, C5$\mathrm{C} 6$ and $\mathrm{C7}-\mathrm{C} 8$. The loops are located between the disulfide bonds. (ii) Short peptides from the $3 \mathrm{~F}$ sequence. The sequences of each of the peptides correspond to one of the loops. In Loop-1 (L-1), C2 was replaced by $G$, and in $L-2, C 3$ was changed to $G$ to restore the disulfide bonds as in the parent 3F. In the case of R10-14, C5 was found to be mutated to $Y$, however, a cysteine residue was selected in the randomized loop. Therefore, a disulfide bond was formed between this cysteine and C6.

\section{Acknowledgements}

The authors are grateful to Mr. Toshikatsu Kobayashi for his kind advices and generous cooperation. We thank Drs. T. Toda and Y. Tamura for cooperation; and J. Yamaguchi, S. Ohtaki and S. Honda for support. This work was supported by the Strategic Research Center (Super COE) Development Program of Special Coordination Funds for Promoting Science and Technology, Ministry of Education, Culture, Sports, Science and Technology (MEXT) and Innovation Center for Start-Ups, National Institute of Advanced Industrial Science and Technology, Japan and in part by New Energy and Industrial Technology Development Organization (NEDO), Japan.

\section{Author details}

'Applied Gene Technology, Institute for Biological Resources and Functions, National Institute of Advanced Industrial Science and Technology, Central 6, 1-1-1, Higashi, Tsukuba, Ibaraki 305-8566, Japan. ${ }^{2}$ Innovation Center for Startups, National Institute of Advanced Industrial Science and Technology, 2-2-2, Marunouchi, Chiyoda-ku, Tokyo, 100-0005, Japan. ${ }^{3}$ Molecular Neurophysiology, Neuroscience Research Institute, National Institute of Advanced Industrial Science and Technology, Central 6, 1-1-1 Higashi, Tsukuba, Ibaraki 305-8566, Japan. ${ }^{4}$ Department of Regulation Biology, Faculty of Science, Saitama University, 255 Shimo-okubo, Sakura-ku, Saitama, 3388570, Japan. ${ }^{5}$ Janusys Corporation, \#508, Saitama Industrial Technology Center, Skip City, 3-12-18 Kami-Aoki, Kawaguchi, Saitama, 333-0844, Japan. ${ }^{6}$ United Graduate School of Drug Discovery and Medical Information Sciences, Gifu University, 1-1 Yanagido, Gifu, Gifu 501-1193, Japan.

${ }^{7}$ Biomedical Research Institute, National Institute of Advanced Industrial
Science and Technology, Central 6, 1-1-1 Higashi, Tsukuba, Ibaraki 305-8566, Japan.

\section{Authors' contributions}

MN designed and performed most of the experiments, analyzed the data and wrote the manuscript. SK prepared the proteins, multiple alignment and protein structures. CT and TS performed cellular assays and wrote a part of the manuscript. MM and NN analyzed the data. TK conceived the study, analyzed the data and wrote the manuscript. All authors approved the final manuscript.

\section{Competing interests}

The authors declare that they have no competing interests.

Received: 14 December 2010 Accepted: 7 January 2011

Published: 7 January 2011

\section{References}

1. Pluckthun A, Schaffitzel C, Hanes J, Jermutus L: In vitro selection and evolution of proteins. Adv Protein Chem 2000, 55:367-403.

2. Smith GP: Filamentous fusion phage: novel expression vectors that display cloned antigens on the virion surface. Science 1985, 228:1315-1317.

3. Lipovsek D, Pluckthun A: In-vitro protein evolution by ribosome display and mRNA display. J Immunol Methods 2004, 290:51-67.

4. Nemoto $\mathrm{N}$, Miyamoto-Sato $\mathrm{E}$, Husimi $\mathrm{Y}$, Yanagawa $\mathrm{H}$ : In vitro virus: bonding of mRNA bearing puromycin at the 3 '-terminal end to the Cterminal end of its encoded protein on the ribosome in vitro. FEBS Lett 1997, 414:405-408

5. Roberts RW, Szostak JW: RNA-peptide fusions for the in vitro selection of peptides and proteins. Proc Natl Acad Sci USA 1997, 94:12297-12302.

6. Yamaguchi J, Naimuddin M, Biyani M, Sasaki T, Machida M, Kubo T, Funatsu T, Husimi Y, Nemoto N: CDNA display: a novel screening method for functional disulfide-rich peptides by solid-phase synthesis and stabilization of mRNA-protein fusions. Nucleic Acids Res 2009, 37(16):e108.

7. Binz HK, Pluckthun A: Engineered proteins as specific binding reagents. Curr Opin Biotechnol 2005, 16:459-469.

8. Nygren PA, Skerra A: Binding proteins from alternative scaffolds. $J$ Immunol Methods 2004, 290:3-28.

9. Binz HK, Amstutz P, Pluckthun A: Engineering novel binding proteins from nonimmunoglobulin domains. Nat Biotechnol 2005, 23:1257-1268

10. Endo T, Tamiya N: Current view on the structure-function relationship of postsynaptic neurotoxins from snake venoms. Pharmacol Ther 1987, 34:403-451.

11. Tsetlin V: Snake venom a-neurotoxin and other 'three-finger' proteins. Eur J Biochem 1999, 264:281-286.

12. Miwa JM, Ibanez-Tallon I, Crabtree GW, Sánchez R, Sali A, Role LW, Heintz N: Lynx1, an endogenous toxin-like modulator of nicotinic acetylcholine receptors in the mammalian CNS. Neuron 1999, 23:105-114.

13. Tsuji H, Okamoto K, Matsuzaka Y, lizuka H, Tamiya G, Inoko H: SLURP-2, a novel member of the human Ly- 6 superfamily that is up-regulated in psoriasis vulgaris. Genomics 2003, 81:26-33.

14. Fry BG, Wüster W, Kini RM, Brusic V, Khan A, Venkataraman D, Rooney AP. Molecular evolution and phylogeny of elapid snake venom three-finger toxins. J Mol Evol 2003, 57:110-129.

15. Teixeira-Clerc F, Menez A, Kessler P: How do short neurotoxins bind to a muscular-type nicotinic acetylcholine receptor? J Biol Chem 2002, 277:25741-25747.

16. Bourne $Y$, Talley $T$, Hansen SB, Taylor $P$, Marchot $P$ : Crystal structure of a Cbtx-AChBP complex reveals essential interactions between snake alpha-neurotoxins and nicotinic receptors. EMBO J 2005, 24:1512-1522.

17. Hirano T, Akira S, Taga T, Kishimoto T: Biological and clinical aspects of interleukin 6. Immunol Today 1990, 11:443-449.

18. Hirano T, Kishimoto T: Interleukin 6 and autoimmune diseases. In Molecular Autoimmunity. Edited by: Talal N. Academic Press; 1991:177-194.

19. Heinrich PC, Behrmann I, Haan S, Hermanns HM, Müller-Newen G, Schaper F: Principles of interleukin (IL)-6-type cytokine signalling and its regulation. Biochem I 2003, 374:1-20.

20. Maes $M$, Yirmyia R, Noraberg J, Brene $S$, Hibbeln J, Perini G, Kubera M, Bob P, Lerer B, Maj M: The inflammatory \& neurodegenerative (I\&ND) 
hypothesis of depression: leads for future research and new drug developments in depression. Metab Brain Dis 2009, 24:27-53.

21. Rasmussen P, Vedel JC, Olesen J, Adser H, Pedersen MV, Hart E, Secher NH, Pilegaard H: humans IL- 6 is released from the brain during and after exercise and paralleled by enhanced IL- 6 mRNA expression in the hippocampus of mice. Acta Physiol (Oxf) 2010.

22. Antil $S$, Servent $D$, Menez A: Variability among the sites by which curaremimetic toxins bind to torpedo acetylcholine receptor, as revealed by identification of the functional residues of alpha-cobratoxin. J Biol Chem 1999, 274:34851-34858.

23. Ferrari DM, Soling HD: The protein disulfide-isomerase family: unravelling a string of folds. Biochem J 1999, 339:1-10.

24. Li J, Zhang H, Liu J, Xu K: Novel genes encoding six kinds of three-finger toxins in Ophiophagus hannah (king cobra) and function characterization of two recombinant long-chain neurotoxins. Biochem J 2006, 398:233-42.

25. Friguet B, Chaffotte AF, Djavadi-Ohaniance L, Goldberg ME: Measurements of the true affinity constant in solution of antigen-antibody complexes by enzyme-linked immunosorbent assay. J Immunol Methods 1985, 77:305-319.

26. Hoogenboom HR: Selecting and screening recombinant antibody libraries. Nat Biotechnol 2005, 23:1105-1116.

27. Braisted AC, Wells JA: Minimizing a binding domain from protein A. Proc Natl Acad Sci USA 1996, 93:5688-5692.

28. Xu L, Aha P, Gu K, Kuimelis RG, Kurz M, Lam T, Lim AC, Liu H, Lohse PA Sun L, Weng S, Wagner RW, Lipovsek D: Directed evolution of highaffinity antibody mimics using mRNA display. Chem Biol 2002, 9:933-942.

29. Cho GS, Szostak JW: Directed evolution of ATP binding proteins from a zinc finger domain by using mRNA display. Chem Biol 2006, 13:139-147.

30. Beste G, Schmidt FS, Stibora T, Skerra A: Small antibody-like proteins with prescribed ligand specificities derived from the lipocalin fold. Proc Natl Acad Sci USA 1999, 96:1898-1903.

31. Binz HK, Stumpp MT, Forrer $P$, Amstutz $P$, Plückthun A: Designing repeat proteins: Well-expressed, soluble and stable proteins from combinatorial libraries of consensus ankyrin repeat proteins. J Mol Biol 2003, 332:489-503.

32. Xie MH, Yuan J, Adams C, Gurney A: Direct demonstration of MuSK involvement in acetylcholine receptor clustering through identification of agonist scFv. Nat Biotechnol 1997, 15:768-771.

33. Rowley MJ, O'Connor K, Wijeyewickrema L: Phage display for epitope determination: a paradigm for identifying receptor-ligand interactions. Biotechnol Annu Rev 2004, 10:151-188.

34. Frederickson S, Renshaw MW, Lin B, Smith LM, Calveley P, Springhorn JP, Johnson K, Wang Y, Su X, Shen Y, Bowdish KS: A rationally designed agonist antibody fragment that functionally mimics thrombopoietin. Proc Natl Acad Sci USA 2006, 103:14307-14312.

35. Cwirla SE, Balasubramanian P, Duffin DJ, Wagstrom CR, Gates CM, Singer SC, Davis AM, Tansik RL, Mattheakis LC, Boytos CM, Schatz PJ, Baccanari DP, Wrighton NC, Barrett RW, Dower WJ: Peptide agonist of the thrombopoietin receptor as potent as the natural cytokine. Science 1997, 276:1696-1699.

36. McConnell SJ, Dinh T, Le MH, Brown SJ, Becherer K, Blumeyer K, Kautzer C, Axelrod F, Spinella DG: Isolation of erythropoietin receptor agonist peptides using evolved phage libraries. Biol Chem 1998, 379:1279-1286.

37. Baneyx F, Mujacic M: Recombinant protein folding and misfolding in Escherichia coli. Nat Biotechnol 2004, 22:1399-1408.

38. Levandoski MM, Caffery PM, Rogowski RS, Lin Y, Shi QL, Hawrot E: Recombinant expression of alpha-bungarotoxin in Pichia pastoris facilitates identification of mutant toxins engineered to recognize neuronal nicotinic acetylcholine receptors. J Neurochem 2000, 74:1279-1289.

39. Love RA, Stroud RM: The crystal structure of alpha-bungarotoxin at $2.5 \AA$ resolution: relation to solution structure and binding to acetylcholine receptor. Protein Eng 1986, 1:37-46.

40. Tsernoglou D, Petsko GA: The crystal structure of a post-synaptic neurotoxin from sea snake at $2.2 \AA$ resolution. FEBS Lett 1976, 68:1-4.

41. Silverman J, Liu Q, Bakker A, To W, Duguay A, Alba BM, Smith R, Rivas A, Li P, Le H, Whitehorn E, Moore KW, Swimmer C, Perlroth V, Vogt M, Kolkman J, Stemmer WP: Multivalent avimer proteins evolved by exon shuffling of a family of human receptor domains. Nat Biotechnol 2005, 23:1556-1561.
42. Qiu XQ, Wang H, Cai B, Wang LL, Yue ST: Small antibody mimetics comprising two complementarity-determining regions and a framework region for tumor targeting. Nat Biotechnol 2007, 25:921-929.

43. Atreya R, Mudter J, Finotto S, Müllberg J, Jostock T, Wirtz S, Schütz M, Bartsch B, Holtmann M, Becker C, Strand D, Czaja J, Schlaak JF, Lehr HA, Autschbach F, Schürmann G, Nishimoto N, Yoshizaki K, Ito H, Kishimoto T, Galle PR, Rose-John S, Neurath MF: Blockade of interleukin 6 trans signaling suppresses T-cell resistance against apoptosis in chronic intestinal inflammation: evidence in crohn disease and experimental colitis in vivo. Nat Med 2000, 6:583-588.

44. Wallenius V, Wallenius $\mathrm{K}$, Ahrén B, Rudling M, Carlsten H, Dickson SL, Ohlsson C, Jansson JO: Interleukin-6-deficient mice develop mature-onset obesity. Nat Med 2002, 8:75-79.

45. Chida D, Osaka T, Hashimoto O, Iwakura Y: Combined interleukin-6 and interleukin-1 deficiency causes obesity in young mice. Diabetes 2006, 55:971-977.

46. Fee D, Grzybicki D, Dobbs M, Ihyer S, Clotfelter J, Macvilay S, Hart MN, Sandor M, Fabry Z: Interleukin 6 promotes vasculogenesis of murine brain microvessel endothelial cells. Cytokine 2000, 12:655-665.

47. Woiciechowsky C, Schöning B, Cobanov J, Lanksch WR, Volk HD, Döcke WD: Early IL-6 plasma concentrations correlate with severity of brain injury and pneumonia in brain-injured patients. J Trauma 2002, 52:339-45.

48. Quintana A, Molinero A, Borup R, Nielsen FC, Campbell IL, Penkowa M, Hidalgo J: Effect of astrocyte-targeted production of IL-6 on traumatic brain injury and its impact on the cortical transcriptome. Dev Neurobiol 2008, 68:195-208.

49. Nishimoto N, Kishimoto T, Yoshizaki K: Anti-interleukin 6 receptor antibody treatment in rheumatic disease. Ann Rheum Dis 2000, 59:21-27.

50. Su JL, Lai KP, Chen CA, Yang CY, Chen PS, Chang CC, Chou CH, Hu CL, Kuo ML, Hsieh CY, Wei LH: A novel peptide specifically binding to interleukin-6 receptor (gp80) inhibits angiogenesis and tumor growth. Cancer Res 2005, 65:4827-4835.

51. Feng J, Li Y, Shen B: The design of antagonist peptide of hlL-6 based on the binding epitope of hIL-6 by computer-aided molecular modeling. Peptides 2004, 25:1123-1131.

52. Martin F, Toniatti C, Salvati AL, Venturini S, Ciliberto G, Cortese R, Sollazzo M: The affinity-selection of a minibody polypeptide inhibitor of human interleukin-6. EMBO J 1994, 13:5303-5309.

53. Zahnd C, Wyler E, Schwenk JM, Steiner D, Lawrence MC, McKern NM, Pecorari F, Ward CW, Joos TO, Plückthun A: A designed ankyrin repeat protein evolved to picomolar affinity to Her2. J Mol Biol 2007, 369:1015-1028.

54. Boder ET, Midelfort KS, Wittrup KD: Directed evolution of antibody fragments with monovalent femtomolar antigen-binding affinity. Proc Natl Acad Sci USA 2000, 97:10701-10705.

55. Wrighton NC, Balasubramanian P, Barbone FP, Kashyap AK, Farrell FX, Jolliffe LK, Barrett RW, Dower WJ: Increased potency of an erythropoietin peptide mimetic through covalent dimerization. Nat Biotechnol 1997, 15:1261-1265.

56. Johnson DL, Farrell FX, Barbone FP, McMahon FJ, Tullai J, Kroon D, Freedy J, Zivin RA, Mulcahy LS, Jolliffe LK: Amino-terminal dimerization of an erythropoietin mimetic peptide results in increased erythropoietic activity. Chem Biol 1997, 4:939-950.

57. Kubetzko $S$, Balic E, Waibel R, Zangemeister-Wittke U, Pluckthun A PEGylation and multimerization of the anti-p185HER-2 single chain Fv fragment 4D5: effects on tumor targeting. J Biol Chem 2006, 281:35186-35201

58. Bock GH, Long CA, Riley ML, White JD, Kurman CC, Fleisher TA, Tsokos M, Brown M, Serbousek D, Schwietermann WD, Nelson DL: Characterization of a new IL-6 dependent human B-lymphoma cell line in long term culture. Cytokine 1993, 5:480-489.

doi:10.1186/1756-6606-4-2

Cite this article as: Naimuddin et al:: Directed evolution of a three-finger neurotoxin by using CDNA display yields antagonists as well as agonists of interleukin-6 receptor signaling. Molecular Brain 2011 4:2. 